\title{
O PT e a Unidade Partidária como Problema*
}

\author{
Alan Daniel Freire de Lacerda
}

\section{INTRODUÇãO}

Crá a unidade partidária um problema relevante no mundo polí$S$ tico? Em outras palavras, as divergências internas de um partido, acompanhadas da possibilidade de cisão inerente a situações de desacordo, produzem efeitos importantes nos processos políticos? No que se refere à formação de coligações eleitorais, coalizões governativas (gabinetes ou ministérios formados por critérios partidários) e coalizões parlamentares, já está bem determinada a importância das divisões internas dos partidos (Laver e Schofield, 1990; cf. os diversos capítulos inclusos em Müller e Strom, 1999). Estas podem efetivamente restringir os graus de liberdade das escolhas feitas por líderes partidários quando da decisão acerca de alianças com outros partidos.

\footnotetext{
*Agradeço os comentários a versões anteriores dos trabalhos feitos por Fabiano Santos, Jairo Nicolau, André Pereira e Ilza Andrade, bem como as observações dos pareceristas anônimos de Dados. Todos foram valiosos. Falhas eventualmente remanescentes são de responsabilidade do autor. Na obtenção dos dados e informações, agradeço aos militantes petistas Leninha, Alex, Carlos, Joaquim e Cida, bem como aos vereadores Fernando Mineiro e Hugo Manso, todos do PT de Natal-RN; igualmente, agradeço as informações dadas por Fernando, dirigente do PST-U no RN.
}

DADOS - Revista de Ciências Sociais, Rio de Janeiro, Vol. 45, nº 1, 2002, pp. 39 a 76. 
Deve-se acrescentar que a política intrapartidária é de interesse em seus próprios termos, particularmente no que diz respeito à alocação de recursos e direitos a membros ou grupos de membros do partido.É verdade que pode existir democracia (no plano nacional) mesmo com organizações partidárias dirigidas de modo inteiramente centralizado, desde que entre as mesmas haja competição aberta, livre e isenta pelos postos eletivos de poder. Não obstante, cabe verificar se, no interior das organizações, vigem procedimentos democráticos de tomada de decisão, ou somente oligarquias alocadas em cúpulas dirigentes.

Neste texto, desenvolvo um modelo analítico de unidade partidária e o aplico ao caso do Partido dos Trabalhadores - PT. O modelo utiliza como variável dependente a possibilidade de ocorrência do caso-limite de cisão partidária, procurando definir as condições sob as quais é mais provável a ocorrência deste evento. As variáveis explicativas são: arranjo institucional intrapartidário, nível de divergência ideológica entre grupos internos e custos eleitorais da cisão ${ }^{1}$. Procurei conferir ao modelo, sobretudo, valor heurístico (e não determinístico), averiguando seu rendimento na pesquisa empírica exposta em seguida. O estudo de caso do PT é justificado não só pela sua importância política no cenário brasileiro, mas também pelo notório faccionalismo existente no partido e a complexidade de sua organização, o que o torna um caso privilegiado para a aplicação do modelo.

A segunda seção apresenta o modelo, ressaltando o elemento verdadeiramente novo da análise, que é a taxonomia de partidos desenvolvida a partir da variável arranjo institucional intrapartidário. A terceira seção procede à aplicação do modelo. Três questões centrais envolvem a análise do PT: a) que impacto as regras institucionais vigentes na arena interna têm sobre o comportamento dos grupos internos; b) quais são as clivagens fundamentais que dividem os petistas; c) que custos externos se impõem sobre os grupos que eventualmente decidam abandonar a legenda. A quarta seção, de conteúdo fortemente informativo, expõe como a correlação de forças internas à agremiação foi se alterando ao longo do tempo, em resposta a desafios eleitorais e sob induções do arranjo institucional adotado pelo partido. A quinta seção avalia o rendimento analítico do modelo, discutindo-o em função do estudo de caso realizado, e apresenta os comentários conclusivos. 


\section{UM MODELO DE UNIDADE PARTIDÁRIA}

\section{Arranjo Institucional Intrapartidário}

Denomino arranjo institucional intrapartidário o conjunto de regras, as quais podem constar em regulamento interno do partido ou consistirem em regras informais reiteradamente cumpridas, que definem 1) a inclusão dos filiados no processo decisório partidário e 2) a institucionalização da competição interna pelos postos de direção partidária. $\mathrm{Na}$ realidade, podemos entender teoricamente o arranjo como um composto dessas duas dimensões de democracia interna, com as organizações partidárias apresentando grande variação (colocando a questão em termos de grau) no que se refere à realização das mesmas. De fato, pode-se fazer uma analogia entre as duas dimensões de democracia interna utilizadas aqui e as duas dimensões teóricas da democratização expostas no clássico Poliarquia (Dahl, 1997), que são a inclusividade - a extensão do direito à participação eleitoral - e a liberalização - oportunidades abertas à competição pública ${ }^{2}$.

Os partidos políticos podem ser apreendidos de maneira similar, com a cautela de não se tomar o grau de realização de democracia interna como um processo de democratização e sim como um atributo desenvolvido historicamente de maneira distinta pelos vários partidos. Em sua forma substancialmente realizada, a inclusão significa o reconhecimento do direito do filiado de base de participar com voz e voto em instâncias internas de decisão, de modo não ocasional, e definido em regulamento interno. Da mesma forma, a institucionalização substancialmente realizada implica o reconhecimento, definido em regulamento interno, da existência de dissidências internas e do direito destas de disputarem os postos de direção partidária. Importa ressaltar que é possível desenvolver uma taxonomia de organizações partidárias em relação ao grau de realização de critérios de inclusão e de institucionalização. O Quadro 1 apresenta tal classificação.

O cruzamento das duas dimensões constantes no quadro define quatro tipos de partidos políticos. Seguem as características de cada um.

O tipo oligarquizado (tipo 1) apresenta baixa ${ }^{3}$ inclusão dos filiados nas instâncias decisórias da organização e reduzida institucionalização da competição para os postos dirigentes. Os membros da base têm poucas oportunidades de manifestar suas preferências acerca da con- 
Quadro 1

Tipos de Arranjo Institucionais Intrapartidários

\begin{tabular}{|l|c|c|c|}
\cline { 3 - 4 } \multicolumn{2}{c|}{} & \multicolumn{2}{|c|}{$\begin{array}{c}\text { Institucionalização da competição } \\
\text { pelos postos de direção partidária }\end{array}$} \\
\cline { 2 - 4 } & Alta & Baixa \\
\hline $\begin{array}{l}\text { Inclusão dos } \\
\text { filiados no } \\
\text { processo decisório }\end{array}$ & Alta & $\begin{array}{c}\text { Inclusivo- } \\
\text { Competitivo }\end{array}$ & $\begin{array}{c}\text { Centralizado- } \\
\text { Inclusivo }\end{array}$ \\
\cline { 2 - 4 } & Baixa & $\begin{array}{c}\text { Centralizado- } \\
\text { Competitivo }\end{array}$ & Oligarquizado \\
\hline
\end{tabular}

dução partidária e não são permitidas dissidências em relação à posição da direção. Portanto, a arena partidária consiste basicamente na própria liderança central do partido. Exemplos são os partidos comunistas organizados sob a tradição do centralismo democrático de inspiração leninista como o PC do B, ou partidos conservadores como o PFL.

O tipo centralizado-inclusivo (tipo 2) apresenta alta extensão do direito à participação dos filiados. Com isso, estes agentes possuem de fato acesso às instâncias de decisão. Contudo, as prerrogativas que daí derivam são limitadas pela baixa institucionalização da competição. A limitação ocorre porque, neste caso, há poucas oportunidades de competição regulada, o que restringe as possibilidades de escolha dos filiados entre propostas e líderes de facções distintas. Ou seja, há competição entre grupos e lideranças internas, mas a disputa entre eles não segue regras preestabelecidas. No Brasil, talvez o PMDB possa ser citado como um exemplo deste tipo, na medida em que possui convenções bastante participativas em certos momentos, mas com competição desordenada entre os grupos.

O tipo centralizado-competitivo (tipo 3) é definido por amplas oportunidades de competição pelos postos de direção partidária, só que combinadas com restrições na participação dos filiados. Caracteristicamente, a arena partidária, embora reduzida, apresenta facções com propostas de condução partidária e lideranças distintas, as quais competem segundo modos ordenados, seja por regulamento ou por práticas informais habitualmente seguidas. Note-se que uma arena restrita pode significar inclusão ocasional dos filiados, os quais deste modo não influem significativamente na condução do partido. O cri- 
tério de inclusão não consiste meramente em uma contagem do número de pessoas com direitos de voz e voto, mas também em uma extensão qualitativa, em termos do número de vezes que a pessoa tem o direito de participar. Portanto, o tipo centralizado-competitivo pode apresentar um grande número de filiados com direitos formais, que, no entanto, freqüentam raramente as reuniões deliberativas da organização. Um exemplo pode ser o PSDB.

O tipo inclusivo-competitivo (tipo 4) apresenta alta inclusão dos filiados no processo decisório interno e alta institucionalização da competição pelos postos de direção partidária. Portanto, é o que realiza substancialmente as duas dimensões de democracia interna, conformando uma arena tanto ampliada quanto competitiva. É curioso notar que o funcionamento de um partido assim estruturado se assemelha em certa medida ao da democracia global: líderes das facções competem entre si pelos votos livres dos filiados, apresentando suas convicções ideológicas e propostas de condução partidária. Partidos deste tipo também sustentam uma ampla liberdade de criação de novas facções, e em geral possuem métodos de representação proporcional no que concerne à eleição da direções partidárias. A existência e atuação das facções é normatizada em regulamento interno. O exemplo brasileiro claro deste tipo é o PT.

No intuito de detalhar o modelo, procederei à construção de hipóteses relativas à questão da unidade/cisão partidária, para cada tipo partidário definido acima.

TIPO 1 - Um partido deste tipo possui fortes incentivos à manutenção da unidade partidária. Em conseqüência das severas restrições à atuação dos filiados, os dirigentes podem conduzir a organização com mínimas ou nulas restrições oriundas da base do partido. Além disso, as decisões são tomadas por uma cúpula de poucos membros, que têm amplos incentivos à construção de uma política unitária e à solução de divergências no âmbito da direção central. Por outro lado, o fato de não haver liberdade de disputa interna pode induzir a saída de lideranças isoladas descontentes com a política do partido. Mesmo assim, como dificilmente se formam facções em partidos assim conformados, saídas eventuais não ameaçam a unidade partidária em seus pilares. 
TIPO 2 - Há uma tensão neste tipo partidário, a qual se dá não só porque os dirigentes devem ser responsivos em um grau razoável à base partidária. A tensão inscreve-se na possibilidade de, no surgimento de lideranças descontentes, estas apelarem à base partidária em busca de apoio. Tal comportamento é digno de crédito, em virtude da ampla extensão de direitos formais de participação, e tem como conseqüência a formação de facções. Três alternativas se abrem para as referidas lideranças diante do baixo nível de liberalização da disputa interna: a) pressionar o comando partidário para obter a regulação da competição; b) recompor-se com a direção a partir da força ampliada advinda do apelo bem-sucedido à base; c) reunir a facção e sair do partido, provocando a cisão. Note-se que as três alternativas também podem ocorrer empiricamente como uma seqüência de movimentos dos atores, desde que o primeiro ou os dois primeiros sejam malsucedidos.

TIPO 3 - O partido centralizado-competitivo possui dois conjuntos de incentivos que promovem a unidade da organização partidária. Primeiro, líderes de facções descontentes com as posições centrais do partido têm a oportunidade regulada de competir no interior da arena; segundo, apelos à base são pouco eficazes, em razão da fraca inserção dos filiados no processo decisório. Portanto, líderes descontentes perseguem melhor seus objetivos compondo, no topo, com líderes de outras facções, procurando alterar gradualmente as posições do partido. Apelos aos filiados serão necessariamente ocasionais, dificilmente acarretando maior profundidade das facções, que permanecem largamente elitizadas.

TIPO 4 - Este tipo partidário possui fortes incentivos à manutenção da unidade partidária, na medida em que garante a todas as facções a oportunidade regulada de competir pelo voto dos filiados e, assim, a possibilidade, maior que em qualquer dos tipos anteriores, do apelo à base partidária, ademais consideravelmente envolvida no processo decisório, ser efetivo. Por outro lado, pode parecer contra-intuitivo meu argumento em relação a este tipo, pois, assim conformada, a organização partidária permite a ocorrência de inúmeros conflitos e ameaças de cisão que eventualmente podem conduzir à fratura do partido. Sustento, contudo, que em um partido que se possa definir como inclusivo os benefícios da unidade organizacional superam os custos da cisão. 
A análise das classes de partidos revela que, em geral, há mais incentivos à manutenção da unidade partidária do que à quebra desta. Todas apresentam induções na direção contrária à cisão, sendo que a classe 2 permanece como aquela sobre a qual incidem maiores induções à fratura. Portanto, arranjos institucionais intrapartidários, considerados isoladamente, dificilmente podem ser responsabilizados por cisões partidárias.

\section{Divergências Ideológicas entre Grupos Internos}

Partidos políticos dificilmente são uniformes do ponto de vista ideológico, a não ser talvez quando bem pequenos ou em sua fase inicial.é plausível presumir que regularmente emergem discordâncias importantes em relação a duas dimensões: à definição de objetivos de longo prazo ou ideologicamente fundacionais do partido e a programas de políticas públicas que o partido oferta ao eleitorado. Uma expectativa plausível que pode ser formulada, desde já, é que, quanto maior a discordância interna, maior o risco de cisão partidária.

A primeira dimensão, em um certo sentido, tem prioridade substantiva sobre a segunda, por duas razões. Porque os objetivos de longo prazo da organização são prévios à construção prática do formato e substância do programa partidário e porque as políticas públicas ofertadas ao eleitorado podem ser derivadas do posicionamento ideológico "de fundo" do partido. Portanto, discordâncias presentes na primeira dimensão possuem maior importância no que toca à existência continuada da organização partidária como agente coletivo minimamente coeso. Nesse sentido, o modelo prediz que as discordâncias na primeira dimensão não serão elevadas se, na comparação dos princípios fundamentais do partido com as suas expressões correspondentes nas facções, for encontrada uma relação de inclusão dessas expressões naqueles princípios.

Contudo, não seria plausível supor genericamente tal prioridade diante da realidade existente nas organizações partidárias. Desafios conjunturais postos pelo calendário eleitoral e a persecução de objetivos conflitantes podem conferir um grande peso à segunda dimensão, que está referida sobretudo aos momentos eleitorais e ao programa ofertado pelo partido ao eleitorado. Em particular, partidos precisam tomar decisões difíceis sobre a perseguição de três objetivos distintos: obtenção de cargos governamentais, a maximização de votos e 
a implementação de políticas públicas que se aproximem de suas preferências ideológicas (Strom, 1990; Müller e Strom, 1999). A busca de um objetivo pode conflitar com a busca de outro, gerando situações dilemáticas nas quais os partidos ou os líderes partidários têm que escolher atingir um deles, a expensas de outro. Tais decisões, claramente alocadas na segunda dimensão, podem gerar tensões internas geradoras de incentivos à cisão da organização.

Suponhamos, por exemplo, que as lideranças de um hipotético partido de esquerda decidam aliar-se a uma agremiação considerada por grande parte de seus militantes como de direita ou distante de sua posição ideológica. Tal resolução tem motivações ligadas à assunção de cargos pelos líderes em uma coalizão governativa. Os referidos militantes, contrariados, podem escolher ameaçar cindir o partido em face de tal iniciativa. Tal decisão tem como motivação a manutenção da posição ideológica tradicionalmente defendida pela agremiação, mas que pode ser prejudicada pela aliança do partido com setores ideologicamente divergentes.

Portanto, considerarei aqui tendo igual peso, para efeito da mensuração da divergência intrapartidária, tanto o desacordo ideológico de longo prazo quanto divergências programáticas de curto e médio prazo. O ponto adquire mais força se admitirmos, o que é forçoso, a existência de partidos políticos cujos compromissos ideológicos de longo prazo são inexistentes ou muito vagos.

Os conflitos ideológicos internos aos partidos podem mudar ao longo do tempo, sendo inerentemente dinâmicos, principalmente em função dos desafios, dilemas e conflitos com os quais as organizações se defrontam no ambiente competitivo externo. Esta observação nos conduz à próxima variável.

\section{Custos Eleitorais da Cisão}

Podemos definir facção como um grupo identificável dentro de um dado partido. Com isso, pretendo excluir os casos de rompimentos individuais de lideranças, fatos às vezes corriqueiros em muitos deles, e que sem dúvida ocorrem naquele que constitui meu estudo de caso. Certamente, também há custos eleitorais e organizacionais a serem considerados no caso de lideranças dissidentes, mas o meu modelo não tem como avaliar como tais custos podem interagir com as outras 
duas variáveis do mesmo. A variedade de motivos por trás de cada rompimento individual torna a questão de difícil tratamento nos limites de minha análise.

Toda facção, ao avaliar a possibilidade de separar-se do partido, deve considerar os custos de tal ato sobre sua inserção continuada no sistema partidário. Se a legenda da qual está saindo possui, por exemplo, um grande número de simpatizantes no eleitorado, a facção pode perder os postos de poder eletivo que detém no sistema político para outras organizações partidárias ou mesmo para o partido político que há pouco tempo a abrigava. Esse risco é notável, pois o valor eleitoral representado pela legenda-mãe, consubstanciado em lealdades ou afinidades sedimentadas no eleitorado, não pode ser substituído. $\mathrm{O}$ ambiente competitivo pode ser demasiado árido para uma legenda nova, a qual tem que se diferenciar da sua agremiação original, ao mesmo tempo que não pode contar mais com os recursos e proteção existentes no partido original (custos organizacionais). Em certos países, características institucionais também devem ser consideradas, tais como um sistema eleitoral majoritário e cláusulas de exclusão como é o caso alemão. Portanto, genericamente falando, a cisão apresenta elevados custos de natureza eleitoral.

Há, contudo, uma forma de reduzir os custos da cisão: a facção pode, no ato de saída do partido, definir um acordo com outro partido, passando a fazer parte deste. Com isso, os custos organizacionais seriam significativamente reduzidos, e o grupo enfrentaria apenas, na pior das hipóteses, custos exclusivamente eleitorais. Portanto, é necessário verificar em cada situação se o rompimento resulta na criação de uma nova legenda ou se o grupo se agrega a um partido já existente. Essa diferença pode ser fundamental para a sobrevivência política dos líderes do grupo em processo de rompimento.

Os custos organizacionais devem ser avaliados caso a caso, mas provisões da legislação são constantes em um dado país, enquanto não ocorrem, é claro, mudanças na legislação. Exemplos incluem exigências legais concernentes a número mínimo de diretórios e filiados. Deve-se considerar também, como elemento integrante dos custos organizacionais, o montante de recursos financeiros disponíveis para o partido. Aqui, podemos claramente explicitar a natureza dos custos de caráter eleitoral. Dentre as três variáveis independentes desenvolvidas no modelo, esta é a que pode ser vinculada a alguns indicadores 
eleitorais. De fato, considero serem três - registre-se que para o caso brasileiro - os indicadores que representam os fatores que entram na composição do custo eleitoral: nível de identificação partidária; votação do partido para a Câmara dos Deputados; número de cadeiras do partido na Câmara dos Deputados.

O nível de identificação partidária nos fornece o percentual do eleitorado que se identifica como simpatizante de uma dada legenda; a votação do partido para a Câmara inclui o peso eleitoral combinado do partido e de seus candidatos individuais (voto de legenda e voto nos candidatos) no pleito para a Câmara dos Deputados; o número de cadeiras reflete o peso parlamentar efetivo do partido após a conversão de votos em cadeiras parlamentares realizada pelo sistema eleitoral.

\section{APLICAÇÃO DO MODELO}

Esta seção tem por escopo a investigação do PT à luz do modelo desenvolvido na seção anterior. Ao final, devemos estar aptos a definir as probabilidades existentes no PT de cisão ou, inversamente, de manutenção da unidade organizacional. O estudo abrange em maior detalhe os anos de 1993 a 1999, cobrindo quatro renovações da direção partidária nacional. Divide-se em quatro subseções: na primeira resumo o contexto de fundação do partido; na segunda apresento meu argumento e as evidências concernentes ao arranjo institucional interno petista; na terceira exponho o argumento e as evidências relativas ao desacordo ideológico interno; na quarta trago argumentos e evidências atinentes aos custos eleitorais de cisão no caso do PT.

\section{Preâmbulo}

O PT foi fundado em 10 de fevereiro de 1980, em um ato de lançamento que reuniu 1200 militantes de dezoito estados. O processo de fundação vinha sendo construído desde janeiro de 1979, quando um congresso de metalúrgicos do Estado de São Paulo conclama para o lançamento de um partido dos trabalhadores ${ }^{4}$. No caminho, uniram-se intelectuais, trabalhadores de outros setores (inclusive rurais), militantes de tendências clandestinas de esquerda, pessoas ligadas às pastorais e às comunidades eclesiais de base da Igreja Católica. Possivelmente caso único no mundo, o PT reuniu marxistas e cristãos desde o início, apresentando uma composição bastante heterogênea que pretendia reunir todos os grupos de esquerda descontentes com as 
possibilidades oposicionistas contidas no MDB, visto como uma oposição moderada ao regime autoritário-militar vigente. Aspirava ser radicalmente diferente dos partidos políticos, inclusive os comunistas, até então existentes no Brasil, tal como eram percebidos pelos petistas: elitistas, de cúpula, nascidos de articulação parlamentar ou por indução de governos. O novo partido tencionava ser fruto direto das lutas sociais, uma expressão destas no campo partidário ${ }^{5}$.

\section{Arranjo Institucional Intrapartidário}

Em suas resoluções, o partido em foco exibe sua preferência ideológica pela vigência de arranjos democráticos no interior da própria organização partidária. Encontrei referências sobre a importância da democracia interna tanto nos documentos pré-fundação (REC 48, 54 e 56) como no Manifesto e Programa de 1980 (REC 66 e 71). Tal predileção corresponde aos fatos? Podemos afirmar, com poucas qualificações, que sim. O PT pode ser incluído sem dificuldades no tipo partidário que, de acordo com meu modelo, foi nomeado inclusivo-competitivo.

Primeiramente, consideremos a dimensão horizontal do processo decisório intrapartidário, qual seja, a inclusão dos filiados. A base filiada tem participação efetiva, garantida por regimento interno e renovada a cada encontro ${ }^{6}$ - o filiado só precisa estar financeiramente em dia com o partido. O PT tem rodadas de encontros municipais praticamente todo ano, o que garante consultas freqüentes aos filiados. Isto se dá por duas razões. Primeiro, nos anos em que há eleições municipais, é usual a ocorrência de encontros para definição de candidaturas e estratégias de campanha. Segundo, para que sucedam os encontros estaduais e o nacional, são necessários encontros municipais (e zonais em cidades grandes, que enviam emissários ao municipal), de onde são retirados representantes para o estadual, que por sua vez envia delegados ao encontro nacional. Qualquer renovação da direção exige um amplo processo que envolve, atualmente, mais de mil encontros municipais e 27 encontros estaduais. Ordinariamente, os anos de renovação nos níveis municipal, estadual e nacional coincidem.

Consideremos agora a dimensão vertical do processo decisório intrapartidário, qual seja, a institucionalização da competição pelos postos de direção partidária. A formação de facções para a competição 
pelo voto dos filiados petistas não só é permitida como regulamentada. Desde o 3ํㅡㄹ Eontro Nacional (1984) ocorrem regularmente disputas entre chapas nas ocasiões de renovação da direção nacional. Sempre houve no PT proporcionalidade direta entre as chapas concorrendo à composição do Diretório Nacional, ou seja, o percentual de delegados obtido por uma determinada chapa no encontro é igual ao percentual de cadeiras ganhas na direção nacional. A conversão é facilitada pelo tamanho do Diretório, em geral mais de 80 membros.

No 5ํㅡㄹ ENT (1987), o partido (ou talvez pudéssemos dizer: a Articulação, corrente majoritária de 1984 a 1993) regulou a existência e atuação das tendências internas (REC 356-359). O objetivo era acabar com os chamados "partidos dentro do partido", tendências e organizações que não reconheciam o caráter estratégico do PT e agiam autonomamente dentro e fora do partido, possuindo sede, imprensa, finanças, direção e disciplina próprias - alguns até com o nome de partido. A resolução reconhece o direito de os filiados se agruparem em tendências, salientando todavia seu caráter interno. Comunicações públicas diretas com a sociedade são proibidas, sendo permitidas apenas comunicações dirigidas ao público interno petista. Torna-se proibido o uso do nome partido pelas tendências, e estas ficam obrigadas a obedecer às deliberações das instâncias partidárias. Não é exagero dizer que a progressiva aplicação da resolução nos anos seguintes afastou plenamente o fantasma do partido-frente (coisa que a resolução explicita e rejeita vigorosamente) que perseguia o partido desde a sua fundação. E, apesar de ser uma ação disciplinar, legitimou a existência da contestação interna organizada.

Contudo, duas limitações à plena institucionalização da competição se verificaram até o início da década de 90. A primeira é que a Articulação reteve o controle das Comissões Executivas Nacionais (em geral de 21 membros) eleitas nos $3^{\circ}$, $4^{\circ}$ (1986) e $5^{\circ}$ Encontros Nacionais. Isto não significa que só estavam presentes na Executiva membros da Articulação, mas sim que esta indicava os membros das outras tendências que poderiam participar da referida instância. A proporcionalidade formalmente assegurada também para a Executiva ${ }^{7}$ passou a vigorar do $7^{\circ}$ Encontro (1990) em diante. A segunda limitação é que até 1991 havia uma exigência mínima de 10\% dos delegados para que a chapa elegesse membros para o Diretório. 
A remoção dessas limitações ampliou os incentivos para a formação de chapas concorrentes, ao reduzir os custos de entrada na Executiva Nacional e, conseqüentemente, possibilitar o acesso a importantes cargos na estrutura do partido. Assim, mesmo chapas com menos de $10 \%$ dos delegados podem eleger um ou dois membros para aquela instância. Deve ser ressaltado que tais mudanças foram efetivadas em um contexto de crise da Articulação, e é cabível sugerir que as novas regras forneceram incentivos para a fratura da corrente majoritária no período de 1990 a 1993 (Melo, 1994:84-91).

É importante assinalar também que, dado o potencial de participação e competição descrito acima, os Encontros petistas são mais ou menos imprevisíveis, podendo resultar em derrotas de dirigentes tidos pelo público externo como imbatíveis (Leal, 1997:35).

Duas outras provisões importantes para a disputa interna devem ser assinaladas: a possibilidade de inscrição de chapas incompletas, o que facilita o acesso de pequenos grupos a cargos nos diretórios e executivas, e as prévias, que ocorrem quando há mais de um pré-candidato a prefeito ou governador, sendo o resultado usualmente homologado pelos Encontros ${ }^{8}$.

O quadro apresentado até aqui sobre o arranjo institucional do PT poderia levar à conclusão de que estamos diante de um partido plenamente democrático, despido de qualquer concentração de poder e autoridade. Em outras palavras, o PT seria imune à tendência de oligarquização que Michels (1962), em um trabalho clássico, já apontava há quase um século, no tocante às organizações partidárias. Tal conclusão, contudo, estaria longe da realidade.

Veja-se o exemplo da Executiva, instância eleita pelo Diretório escolhido no Encontro, e composta por membros do próprio Diretório. As Comissões Executivas (nos níveis municipal, estadual e nacional) possuem, na prática e em geral, mais poderes que os Diretórios. Estes são instâncias de deliberação superiores às Executivas, porém sofrem problemas de obtenção de quórum e de coordenação dos trabalhos. Em virtude do grande número de pessoas, suas reuniões são bem mais raras que as das Executivas, além do que sua pauta é determinada pelos membros destas últimas. Como evidência da preeminência das Executivas, há o fato de o Diretório Nacional delegar freqüentemente autoridade à Executiva Nacional para decidir um amplo con- 
junto de questões, como regulamentos de Encontros e redação final de resoluções políticas.

O PT, portanto, não é imune aos efeitos de sua transformação em uma grande "máquina" dirigida à competição eleitoral de massas com o conseqüente fortalecimento dos líderes em relação à base. Este trabalho não nega o fato, trivial na análise política, de que partidos formam uma elite partidária, que toma a maior parte das decisões e pauta as discussões e deliberações da base. Mesmo assim, não seria acurado desconsiderar o fato de que a base filiada é detentora última da autoridade dentro do partido. Os próprios líderes das facções petistas não descuidam desse fato básico, coisa que pode ser notada quando acenam à base com discursos dirigidos ao conflito interno.

\section{Divergências Ideológicas entre Grupos Internos}

Nesta subseção, minha meta é aferir a extensão e o caráter do desacordo ideológico entre as facções petistas. Para tal, retirei os principais elementos do que considero ser a matriz ideológica do partido, através de suas resoluções sobre o socialismo, e os comparei com suas expressões correspondentes nas teses ${ }^{9}$ apresentadas pelas facções.

Três objeções podem se antepor a esse procedimento. Primeiro, as resoluções sobre o socialismo, aprovadas nos anos de 1981, 1987, 1990 e 1991, o foram em contextos de considerável conflito interno, havendo a possibilidade de existirem até hoje setores do partido que as rejeitem. Segundo, resoluções e teses petistas apresentam consideráveis ambigüidades, o que dificulta uma apreensão coerente dos elementos definidores do pensamento petista (Azevedo, 1995). Terceiro, que essas formas de discurso se encontram eivadas de retórica, não expressando as razões reais e práticas do comportamento dos atores.

Respondo à primeira objeção assinalando que as referidas resoluções são utilizadas freqüentemente pelas facções em suas teses (no período 1993-99), inclusive como instrumento de crítica a outros grupos, o que indica que já fazem parte do manancial comum de idéias pertencentes à organização como um todo. À segunda replico que o que farei adiante é intencionalmente uma leitura que busca perceber os motivos condutores que deram origem aos documentos, portanto, não procuro detectar eventuais problemas de coerência (que, a meu ver, não são de maneira alguma graves). Contesto a terceira objeção afir- 
mando que estou referido aqui, sobretudo, aos efeitos visíveis do comportamento dos atores, tanto no que concerne ao discurso (apresentação de teses) como no que diz respeito à ação (formação de chapas e tendências). Estou em condições de asseverar a importância de tais efeitos na organização partidária ora em estudo, mas não "em condições de atestar a falsidade ou correção das razões fornecidas pelos atores políticos para dotar de significado e finalidade as suas ações e escolhas" (Lessa, 1999:15; ver também pp. 14 e 24). Ou, dito de outra forma, a retórica é importante.

Vejamos as principais características ideológicas presentes nos documentos fundacionais do partido ${ }^{10}$. O PT, é claro, podia ser definido então, e hoje com algumas diferenças, como um partido de esquerda de matriz socialista-democrática. Mas como se apresentava esta característica no momento fundacional (1979-1981)? A idéia de nascer diretamente das lutas sociais fornece a pista: o trabalho de base fundamenta toda a ação e doutrina do partido, portanto, a base deve sempre ser consultada antes de qualquer decisão partidária de grande importância. Deste ponto, podemos ressaltar igualmente a prioridade ideológica das lutas sociais em relação à inserção na institucionalidade democrática. E quanto ao socialismo? O PT procurava construir uma concepção de socialismo que se harmonizasse com a luta democrática então em curso, mas diante da variedade de posições no partido, seria muito difícil e até mesmo indesejável explicitar uma concepção definida de socialismo, especialmente dada a recusa dos petistas aos modelos social-democrata e socialista soviético. Lula, em um discurso histórico à primeira convenção nacional em $1981^{11}$, estabeleceu a posição mediana petista possível.

“O socialismo que nós queremos se definirá por todo o povo, como exigência concreta das lutas populares, como resposta política e econômica global a todas as aspirações concretas que o PT seja capaz de enfrentar. [...] O socialismo que nós queremos irá se definindo nas lutas do dia-a-dia, do mesmo modo como estamos construindo o PT. O socialismo que nós queremos terá que ser a emancipação dos trabalhadores. E a libertação dos trabalhadores será obra dos próprios trabalhadores." (REC 114)

A concepção de socialismo petista é, portanto, bastante vinculada às lutas presentes e específicas travadas no Brasil, vide a ênfase "nas lutas do dia-a-dia" e nos problemas concretos dos trabalhadores. No $5^{\circ}$ 
Encontro Nacional (1987), há um avanço no que toca à questão da democracia. O PT compromete-se com a democracia, embora mencione que sob o capitalismo esta só pode ser de caráter formal. Após um período de acúmulo de forças e disputa de hegemonia na sociedade civil e nas instituições políticas, poderá acontecer a conquista do poder pelos trabalhadores, e a liquidação do poder burguês com a instalação de um Estado socialista ${ }^{12}$. A resolução define o socialismo, portanto, como um objetivo estratégico do partido, mas defende que a construção socialista começa desde já, mediante o estímulo às formas de democracia direta e às lutas de movimentos setoriais como o de mulheres, negros e homossexuais - eis novamente o pluralismo petista. $\mathrm{O}$ documento afirma explicitamente que reforma e revolução são táticas que podem ser harmonizadas. Desta forma, o PT consegue conciliar a prática militante envolvida intensamente em atividades tipicamente reformistas (movimento sindical e movimentos sociais urbanos reivindicatórios) e um horizonte mais amplo do que a prática cotidiana (REC 303-327).

No 7o Encontro Nacional (1990), o PT atribui valor estratégico também à democracia. "Para nós, ela é, a um só tempo, meio e fim, instrumento de transformação e meta a ser alcançada" (REC 429). A identidade democrática é vinculada ao caráter anticapitalista do projeto partidário, pois democracia plena aí significa superação do capitalismo. A identidade democrática é vinculada também à própria estrutura interna do partido (o partido deve prefigurar o socialismo democrático futuro mediante sua democracia interna) e à relação deste com os movimentos sindical e sociais (distinção e autonomia entre o partido e os movimentos). Nessas resoluções, sob o influxo da queda do Muro de Berlim, são rejeitadas de modo mais sistemático as opções da social-democracia e do socialismo real, inclusive, no que toca a este último, reiterando o apoio aos movimentos de libertação contrários aos regimes de tipo soviético então em crise (REC 429-435).

No $1^{\circ}$ Congresso Nacional ${ }^{13}$ (1991), último momento de elaboração programática sistemática sobre o socialismo, o PT rejeita a ditadura do proletariado, identificando-a com a ditadura de partido único. Recusa igualmente a idéia de abolir o mercado por decreto, admitindo sua existência no processo de construção socialista, desde que "sob controle do planejamento democrático e estratégico e orientado socialmente", sendo prevista sua abolição no final do processo (REC 502). "Para o PT, socialismo é sinônimo de radicalização da democracia" 
(REC 499). Portanto, os petistas não se satisfazem com a democracia realizada apenas na dimensão político-institucional, propondo sempre sua extensão aos campos social e econômico, o que chamam de radicalização da democracia - ou socialismo.

Podemos perceber, portanto, neste breve resumo da evolução da concepção socialista do PT, a persistência, evidentemente com profundos desenvolvimentos, da matriz ideológica fundacional, sintetizada pelo discurso de Lula em 1981. Aliás, trechos do discurso são reiterados inclusive nas resoluções do $1^{\circ}$ Congresso. Trata-se de uma ideologia socialista que valoriza o trabalho de base nas lutas sociais, a democracia interna das organizações, as lutas sociais cotidianas e específicas como parte integrante do processo global de transformação rumo ao socialismo, a democracia como valor estratégico.

De acordo com o meu modelo, as divergências entre as facções de um partido podem ser divididas em duas dimensões. A primeira é relativa à definição de objetivos de longo prazo ou ideologicamente fundacionais do partido; a segunda refere-se aos programas de políticas públicas ofertados ao eleitorado pelo partido em função do calendário eleitoral. Importa agora a questão de como proceder para definir e mensurar o conflito ideológico no caso em pauta, operacionalizando a variável e suas duas dimensões. Proponho aqui, para consideração deste tópico, uma divisão genérica do partido em dois blocos ideológicos, esquerda e direita, cujas particularidades (líderes e chapas) serão detalhadas na próxima seção.

O discurso básico da esquerda partidária, por exemplo, no que se refere ao conflito interno, é o de afirmar que os setores partidários adversários valorizam demasiadamente o espaço institucional em detrimento da luta social, que seria mais importante para a construção do socialismo. Como a luta social é de fato prioritária em várias resoluções partidárias, ao ressaltar sua fidelidade aos princípios ideológicos e atestar o afastamento da ala direita do partido desses mesmos princípios, as correntes de esquerda possuem uma poderosa ferramenta de persuasão que pode ser dirigida à base filiada.

O discurso da ala direita, tomando também um exemplo, costuma salientar que ambas, tanto a luta social como a institucional, têm a mesma importância e devem ser desenvolvidas em conjunto, no que também é apoiada por várias resoluções de Encontros. Além disso, há 
uma maior ênfase em questões programáticas e de desenhos gerais de políticas públicas específicas, o que demonstra uma maior atenção às

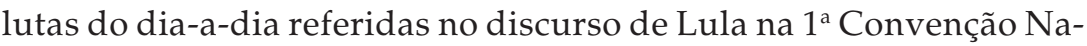
cional. Deve-se ressaltar também que há um certo consenso entre os membros desse bloco de que os mais concentrados na luta interna são seus adversários da esquerda petista, ressaltando que eles próprios promovem melhor a unidade partidária.

Os princípios ideológicos petistas estão necessariamente referidos ao socialismo democrático. Cabe, portanto, fazer uma comparação entre as propostas das facções internas, no intuito de perceber diferenças entre os grupos no que toca à concepção substantiva de socialismo e ao processo de realização do objetivo socialista. Agrupo, para efeito de análise, os princípios ideológicos fundamentais do PT em três grandes elementos, conforme o Quadro 2 indica, e os comparo com o que sustento ser a atitude genérica das alas para com tais matrizes.

Nas três linhas do quadro, existem áreas de concordância entre os dois grandes campos partidários. As maiores discordâncias situam-se nas primeira e terceira linhas, e estão referidas basicamente à principal questão do PT na década: a inserção do partido nas instituições políticas. Na primeira, é possível perceber a influência da percepção petista, segundo a qual houve uma redução do nível de associativismo na sociedade brasileira, algo que o PT não desejou e com o qual tem que lidar. $\mathrm{O}$ fato é que o partido avança no plano eleitoral mesmo sem mobilização social prévia. Como isso dá muito peso interno a parlamentares e militantes remunerados em geral, o partido institucionaliza-se e sofre processos de burocratização (Novaes, 1993). A primeira linha reflete modos divergentes de lidar com o problema, não um desacordo fundamental.

Na terceira linha, o desacordo é mais profundo, referido ao papel das instituições no processo de realização do socialismo. A esquerda não tem compromissos inequívocos com a institucionalidade liberal, embora rejeite, naturalmente, opções ditatoriais. A direita vincula a luta pelo socialismo à radicalização da democracia, com a manutenção e aperfeiçoamento da institucionalidade liberal ${ }^{14}$. Contudo, não há uma incompatibilidade incontornável nesta questão, dado que há concordância em relação à insuficiência da democracia realizada apenas na esfera política. 
O PT e a Unidade Partidária como Problema

Quadro 2

Configuração Interna dos Princípios Ideológicos Petistas (1993-1999)

\begin{tabular}{|c|c|c|}
\hline $\begin{array}{l}\text { Elemento da Matriz } \\
\text { Ideológica }\end{array}$ & Esquerda & Direita \\
\hline $\begin{array}{c}\text { Trabalho de base na luta } \\
\text { social e o PT como } \\
\text { expressão desta ação }\end{array}$ & $\begin{array}{c}\text { A luta social deve } \\
\text { preceder o avanço } \\
\text { institucional. A ampliação } \\
\text { do poder do partido só } \\
\text { faz sentido dentro de um } \\
\text { quadro de crescimento da } \\
\text { mobilização e da } \\
\text { organização populares. }\end{array}$ & $\begin{array}{c}\text { Lutas social e } \\
\text { institucional caminham } \\
\text { juntas. Mesmo sem } \\
\text { mobilização, é possível } \\
\text { avançar no campo } \\
\text { institucional. É possível } \\
\text { usar as instituições para a } \\
\text { mobilização. }\end{array}$ \\
\hline $\begin{array}{l}\text { Lutas específicas e } \\
\text { concretas como parte do } \\
\text { processo global de } \\
\text { transformação }\end{array}$ & $\begin{array}{l}\text { São valorizadas desta } \\
\text { maneira, sim. Mas o } \\
\text { partido deve } \\
\text { encaminhá-las na direção } \\
\text { de seus objetivos de curto } \\
\text { e médio prazo, já com um } \\
\text { sentido de longo prazo no } \\
\text { rumo do socialismo. }\end{array}$ & $\begin{array}{l}\text { São valorizadas desta } \\
\text { maneira, sim. Mas o } \\
\text { partido deve } \\
\text { encaminhá-las na direção } \\
\text { de seus objetivos de curto } \\
\text { e médio prazo, } \\
\text { acumulando forças para o } \\
\text { objetivo estratégico. }\end{array}$ \\
\hline $\begin{array}{c}\text { Socialismo democrático e } \\
\text { democracia como valor } \\
\text { estratégico }\end{array}$ & $\begin{array}{c}\text { O objetivo socialista deve } \\
\text { ser realizado } \\
\text { democraticamente, mas } \\
\text { não com o quadro } \\
\text { institucional } \\
\text { democrático-liberal. A } \\
\text { democracia deve } \\
\text { expandir-se para as } \\
\text { esferas social e } \\
\text { econômica. Só a } \\
\text { democracia política é } \\
\text { insuficiente. Valorização } \\
\text { de formas de democracia } \\
\text { direta. }\end{array}$ & $\begin{array}{c}\text { Expansão da democracia } \\
\text { da esfera política para as } \\
\text { esferas social e } \\
\text { econômica. Só a } \\
\text { democracia política é } \\
\text { insuficiente. Realização } \\
\text { do socialismo com } \\
\text { manutenção das } \\
\text { instituições } \\
\text { representativas } \\
\text { democrático-liberais, que } \\
\text { devem ser aperfeiçoadas, } \\
\text { e formas de democracia } \\
\text { direta. }\end{array}$ \\
\hline
\end{tabular}

Fontes: Caderno de Pré-Teses de 1993 e Cadernos de Teses de 1995, 1997 e 1999.

Com referência à dimensão programática, optei aqui por utilizar a questão da política de alianças como um indicador aproximado das divergências no que se refere às políticas públicas a serem propostas ao eleitorado. A política de alianças do PT é uma questão bastante polêmica dentro do partido e pode ser relacionada imediatamente aos programas de governo. Além disso, podemos vinculá-la diretamente à dimensão dos princípios ideológicos. Isso porque a ampliação do 
campo de aliados - políticos e/ou sociais - requer um programa distanciado da busca pelo socialismo, objetivo que não interessa a vários aliados. Por outro lado, a diminuição do campo de aliados permite o desenho de um programa menos distante do objetivo estratégico, portanto mais puramente petista.

Relaciono abaixo as posições das facções tendo em vista a política de alianças com outros partidos ${ }^{15}$. Aparecem igualmente propostas de grupos que seriam subunidades dos dois grandes campos. Tais distinções são delineadas na próxima seção, e não afetam a direção do argumento apresentado. As propostas de alianças feitas nos Encontros são referidas às eleições do ano seguinte.
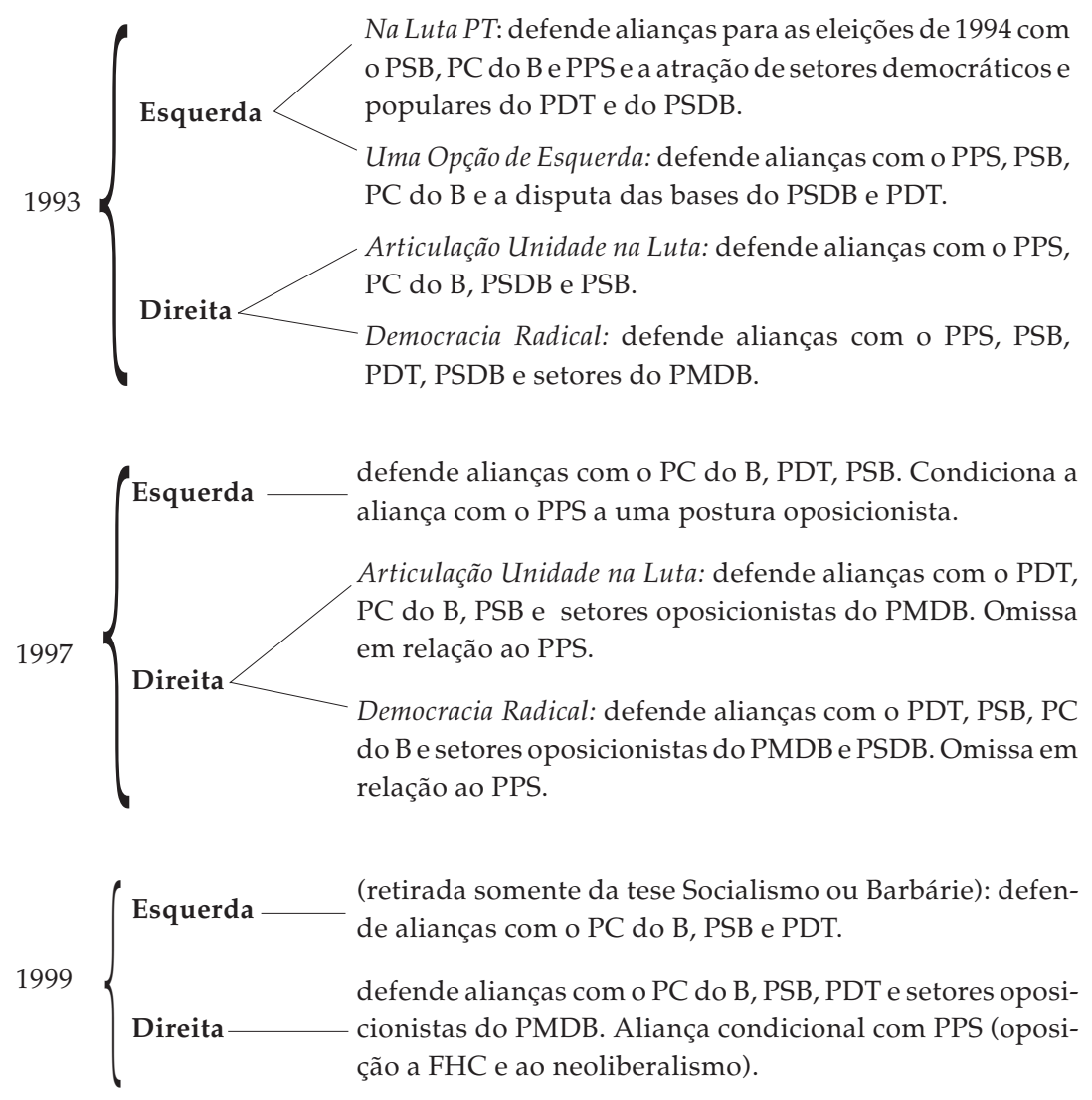

Como se pode perceber, a esquerda partidária propõe sistematicamente um arco de alianças mais restrito que a direita do partido, o que 
reflete uma forte divergência no que se refere à tática do partido para chegar ao governo federal e mantê-lo politicamente. A esquerda salienta que a sustentação de um governo encabeçado pelo PT deve estar prioritariamente amparada nos movimentos sociais e partidos de esquerda, enquanto a direita considera igualmente fundamental um arco partidário-parlamentar que inclua setores do centro político-ideológico brasileiro.

\section{Custos Eleitorais da Cisão}

As evidências que apresentarei adiante nos levam à seguinte conclusão: há elevados custos eleitorais para qualquer facção que decida sair do PT. Aliás, sempre houve vaticínios e previsões de cisão partidária, tanto dentro como fora do partido, como quando se dizia que o partido era uma frente sempre à beira da cisão ou que só se mantinha unido por causa da candidatura presidencial de Lula, argumento especialmente divulgado em referência às eleições de 1989 e 1994.

A única cisão significativa que a organização sofreu em vinte anos foi a saída da tendência Convergência Socialista, em 1992. A tendência formou o Partido Socialista dos Trabalhadores-Unificado (PST-U), que até o momento não elegeu nenhum representante para o Congresso Nacional e Assembléias Legislativas. Sua votação variou de cerca de 0,2\% a 0,3\% de 1994 a 1998 nos pleitos para a Câmara. O PST-U, em seu início, foi composto majoritariamente pela tendência Convergência Socialista. A CS foi expulsa do PT em maio de 1992, mas o rompimento já se mostrava inevitável há algum tempo dadas as divergências existentes. A expulsão ocorreu em um contexto de desobediência permanente do grupo às diretrizes da direção nacional petista.

Um caminho promissor seria avaliar saídas individuais de lideranças importantes. O PT tem colecionado defecções dessa natureza em escala importante, curiosamente mais concentradas à direita do espectro interno, com destaque para três ex-prefeitos de capitais (Maria Luísa Fontenelle, Luiza Erundina e Darci Accorsi) e um governador (Victor Buaiz). Tais movimentos não constituem reais cisões, de acordo com nossa definição, pois nenhum deles levou consigo um grupo identificável dentro do PT. Vários quadros ligados à administração Erundina, p. ex., continuaram no partido, hoje compondo a gestão Suplicy. Uma avaliação impressionista das rupturas petistas nos diria que elas ocorrem sobretudo em função de divergências políticas entre 
os governantes e amplos grupos partidários, além de cálculos político-eleitorais feitos pelas próprias lideranças em processo de abandono da legenda. Em relação a este último ponto, é importante notar que Erundina e Accorsi (é cedo para avaliar Buaiz, e Fontenelle, após uma passagem pela Câmara, perdeu importância política) têm sofrido derrotas eleitorais expressivas em pleitos majoritários ${ }^{16}$, a meu ver, indicativas de custos eleitorais e, no caso da ex-prefeita, também organizacionais, em particular na eleição municipal de 2000.

O fato é que todas as correntes petistas possuem mandatários eleitos, cujas posições podem ser perdidas no caso de uma saída do partido. O PT possui consideráveis níveis de identificação partidária no eleitorado para os padrões do Brasil, onde a maioria dos eleitores não tem preferência partidária (pelo menos até 1994). Em 1994, o partido detinha, segundo pesquisa do instituto Datafolha, níveis de identificação partidária de $15 \%$, em maio, e $11 \%$, em setembro, este último no pior momento da campanha "Lula Presidente". O PMDB, outro partido que possui consideráveis níveis de identificação partidária, atingiu $13 \%$ nos dois momentos ${ }^{17}$.

O PT apresenta, ademais, uma votação crescente para a Câmara, e sua bancada na Casa tem se ampliado expressivamente a cada pleito, embora o ritmo de crescimento tenha diminuído em 1994 e 1998. A Tabela 1 expõe o processo.

Tabela 1

PT e Câmara dos Deputados

\begin{tabular}{l|c|c}
\hline Eleições & $\begin{array}{c}\text { Votação } \\
\text { (N e \%) }\end{array}$ & $\begin{array}{c}\text { Número de Cadeiras } \\
\text { (N e \%) }\end{array}$ \\
\hline \multirow{2}{*}{1982} & 1.458 .719 & 8 \\
& $(3,5 \%)$ & $(1,7 \%)$ \\
1986 & 3.204 .390 & 16 \\
& $(6,9 \%)$ & $(3,3 \%)$ \\
1990 & 4.128 .052 & 35 \\
& $(10,2 \%)$ & $(7 \%)$ \\
1994 & 5.859 .347 & 49 \\
& $(12,8 \%)$ & $(9,6 \%)$ \\
1998 & 8.786 .499 & 58 \\
& $(13,2 \%)$ & $(11,3 \%)$ \\
\hline
\end{tabular}

Fontes: Nicolau (1998) e dados cedidos pelo autor. 
Não é possível presumir que os líderes das facções não levem em consideração tal força eleitoral e parlamentar, ainda em crescimento, quando cogitam de propor a seus liderados uma eventual saída do partido. Afinal, as posições eletivas realçam o peso interno da facção, propiciam a mobilização de recursos materiais e humanos importantes tanto para a disputa interna quanto para a competição eleitoral, e garantem a sobrevivência política dos líderes e dos grupos ao seu redor.

\section{FACÇÕES, CHAPAS E ENCONTROS}

O Partido dos Trabalhadores é classificado externamente de acordo com diversos pontos de vista. À luz do senso comum, seja este expresso por setores da imprensa ou importantes emissores de opinião política, o partido ora é visto como uma frente mal unida de grupelhos e tendências, ora como um composto de figuras eleitoralmente fortes de posições moderadas em conflito com burocratas radicais alojados em tendências internas marxistas. Ambas as visões não encontram confirmação nas evidências disponíveis.

De 1983 a 1993, o PT contou com uma facção majoritária, a Articulação ${ }^{18}$, que fixava em larga escala os rumos do partido. Esta corrente pode ser definida como uma espécie de grande centro petista, com forte presença sindical, reunindo em seu seio uma diversidade similar à existente no partido como um todo, embora com menor presença dos setores marxistas. A Articulação deparou-se, em todos os Encontros em que houve renovação da direção nacional, com a oposição de setores que podemos designar como esquerda partidária, basicamente grupos vinculados mais fortemente aos ideários marxistas. No último Encontro surge um grupo à direita da corrente majoritária. A Tabela 2 expõe as chapas que concorreram ao Diretório Nacional, bem como seu percentual de delegados, em quatro Encontros nacionais.

Nos $3^{\circ}$ e $4^{\circ}$ Encontros, a Articulação enfrenta a oposição unificada da esquerda partidária, superando-a com facilidade. No $5^{\circ}$, a minoria de esquerda divide-se em três chapas, perfazendo no total 40,6\% dos delegados, seu melhor resultado no período. No $7^{\circ}$ Encontro Nacional, a corrente majoritária apresenta seu pior resultado (56\% dos delegados), mas sustenta uma maioria tranqüila tendo em vista a divisão dos outros grupos. A esquerda partidária, dividida em duas chapas, também exibe seu pior resultado no conflito interno no período $(27 \%$ dos delegados). Determinante para as perdas foi a força adquirida 
Alan Daniel Freire de Lacerda

Tabela 2

Chapas Concorrentes ao Diretório Nacional do PT

1984-1990

\begin{tabular}{|c|c|c|c|}
\hline & Articulação & Esquerda Partidária & Direita \\
\hline 3을 ENPT (1984) & $\begin{array}{l}\text { Por um PT de Massas } \\
175 \text { votos }(65,8 \%)\end{array}$ & $\begin{array}{l}\text { O PT se Constrói na } \\
\text { Luta } \\
93 \text { votos }(34,2 \%)\end{array}$ & Inexistente \\
\hline $4^{\circ}$ ENPT (1986) & $\begin{array}{l}\text { Articulação por uma } \\
\text { proposta } \\
\text { democrática, de } \\
\text { massas e socialista } \\
\text { para o PT } \\
226 \text { votos }(72,2 \%)\end{array}$ & $\begin{array}{l}\text { Alternativa Operária } \\
\text { e Popular } \\
87 \text { votos }(27,8 \%)\end{array}$ & Inexistente \\
\hline 5을 ENPT (1987) & $\begin{array}{l}\text { Por um PT de Massas } \\
212 \text { votos }(59,4 \%)\end{array}$ & $\begin{array}{l}\text { O PT pela Base ( } 46 \\
\text { votos); Em Defesa da } \\
\text { Democracia (13 } \\
\text { votos); Luta } \\
\text { Socialista ( } 86 \text { votos) } \\
\text { Total: } 145 \text { votos } \\
(40,6 \%)\end{array}$ & Inexistente \\
\hline 7을 ENPT (1990) & $\begin{array}{l}\text { Articulação da Luta } \\
\text { Socialista } \\
(56 \%)\end{array}$ & $\begin{array}{l}\text { PT de Luta e de } \\
\text { Massas }(11 \%) ; \\
\text { Alternativa Socialista } \\
\text { e Revolucionária } \\
(16 \%) \\
\text { Total: } 27 \%\end{array}$ & $\begin{array}{l}\text { Socialismo e } \\
\text { Liberdade } \\
(17 \%)\end{array}$ \\
\hline
\end{tabular}

Fonte: REC. Os números absolutos não estão disponíveis.

pela chapa Socialismo e Liberdade (17\% dos delegados), grupo liderado por José Genoíno e Eduardo Jorge que procurava se diferenciar da Articulação e diminuir a influência da esquerda partidária ${ }^{19}$.

É importante salientar que a formação da Articulação, patrocinada por Lula e vários líderes próximos a ele em 1983 (o assim chamado grupo dos 113), foi uma resposta à desarticulação exibida pelo partido nos seus primeiros anos, particularmente na eleição de 1982. Talvez até 1983, o PT realmente se apresentasse como uma frente não coesa de tendências e grupos. A solução fornecida pela composição de uma maioria estável permitiu ao partido avançar no processo de elaboração programática, progredir na conquista de postos eletivos e ampliar nacionalmente a organização partidária.

62 
De todo modo, o PT chega ao início da década de 90 com uma configuração política interna ainda marcada pela dominância da corrente majoritária Articulação, como vimos no preâmbulo desta seção. Tal configuração se vê, a partir daí, posta sob tensão pelos efeitos de dois processos:

$1^{\circ}$ ) a crescente inserção do partido na competição eleitoral, acrescida do intenso desgaste da direção eleita em 1990. A importância ampliada dos mandatos parlamentares com suas estruturas de assessoria próprias, e conseqüente autonomização em relação às instâncias de direção partidária, fornece insumos ao conflito interno, na medida em que o partido vai ficando cada vez mais "institucionalizado", o que contraria a tradição petista de expressão das lutas sociais. Assim, o avanço do partido no campo das instituições políticas representativas define uma linha de intensa polêmica interna;

$2^{\circ}$ ) a aplicação do Regulamento das Tendências (1987) e o uso universal da representação proporcional na competição interna. Ao garantir um certo nível de enforcement dentro do PT, a Articulação obrigou as numerosas tendências da esquerda partidária a dirigirem mais fortemente seus recursos para a ocupação de espaços dentro do partido. Tais grupos passaram a limitar seu horizonte de militância à inserção no PT e à disputa pelos rumos da legenda, procurando inclusive atrair setores da corrente majoritária, dada a heterogeneidade desta, para seus projetos. O mesmo fez a corrente formada à direita da Articulação. Com a proporcionalidade plena na Executiva Nacional, tornou-se menos custoso para os grupos descontentes na Articulação organizarem um grupo à esquerda dos dirigentes da corrente.

Tais tensões deságuam no $8^{\circ}$ Encontro Nacional, ocorrido em junho de 1993, no qual se concretiza previsivelmente a cisão da Articulação, sendo formada uma maioria da esquerda partidária. Para uma melhor compreensão deste processo e também de eventos posteriores, exponho a seguir um breve sumário das principais facções petistas, com suas lideranças principais e algumas ações e características.

Na Luta PT: setor mais esquerdista do partido nos encontros de 1993 e 1995, com chapa própria no primeiro e compondo a chapa Socialismo e Democracia no segundo. Extingue-se depois de 1995. Contudo, os mesmos setores participaram das chapas Luta Socialista e Socialismo ou Barbárie, respectivamente em 1997 e 1999 (à exceção do grupo O 
Trabalho em 1999, que lançou chapa própria: Fiel ao PT das Origens). Composto principalmente pelas correntes Força Socialista, Tendência Marxista e $O$ Trabalho. Formado majoritariamente por marxistas de diversos matizes. Principais lideranças ${ }^{20}$ : Luiz Eduardo Greenhalgh (Dir. Nac. até 1997), Markus Sokol (Dir. Nac.), Ronald Rocha (Dir. Nac.), Jorge Almeida (Dir. Nac.) e Edmilson Rodrigues (prefeito de Belém eleito em 1996).

Democracia Socialista (DS): tendência interna de origem trotskista, sempre definiu sua política como de "disputa de rumos", procurando firmar o PT como partido revolucionário e estratégico na luta pelo socialismo. Em 1993 integrou-se à chapa Uma Opção de Esquerda, eixo da guinada à esquerda do partido, junto com a Articulação de Esquerda e grupos regionais. Em 1995 e 1997, compôs as chapas Socialismo e Democracia e Luta Socialista, respectivamente. Em 1999, apresentou-se com chapa própria: Nosso Tempo. Principais lideranças: João Machado (Dir. Nac.), Joaquim Soriano (Dir. Nac.), Heloísa Helena (Dir. Nac. a partir de 1995 e senadora por Alagoas eleita em 1998) e Raul Pont (Dir. Nac., prefeito de Porto Alegre eleito em 1996).

Articulação de Esquerda: grupo formado pela cisão da corrente majoritária em 1993. Constituído por setores que pretendiam compor uma nova hegemonia no $\mathrm{PT}$, inclinada à esquerda, diante do que consideravam o "eleitoralismo" predominante na direção de 1990-93 e em outros setores da Articulação. Principal facção da chapa Uma Opção de Esquerda. Em 1995 integrou a chapa Socialismo e Democracia, à exceção dos setores agrupados em torno de lideranças como Rui Falcão (dep. est. por São Paulo eleito em 1990 e 1994, presidente interino do partido durante a licença de Lula para a campanha presidencial de 1994) e Cândido Vacarezza (Dir. Nac. a partir de 1995). Tais lideranças passaram a fazer composições com a ala direita nos Encontros de 1995, 1997 e 1999. Em 1999, a corrente integrou a chapa Socialismo ou Barbárie. Principais lideranças que continuaram na corrente: Arlindo Chinaglia, exceto em 1999 (eleito por São Paulo em 1990 deputado estadual e em 1994 e 1998, federal, Dir. Nac. a partir de 1995), Sonia Hypólito (Dir. Nac.), Adão Pretto (dep. fed. pelo Rio Grande do Sul) e Luciano Zica.

Articulação Unidade na Luta: por vezes tido como o grupo mais pragmático do partido, principal facção da ala direita, é o setor que agrega os políticos mais conhecidos do PT, os quais constituíam o nú- 
cleo dirigente da antiga Articulação. Teve chapa própria em todos os Encontros analisados. Mantém uma política de aliança sistemática com a corrente Democracia Radical. Principais lideranças: Luiz Inácio Lula da Silva, José Dirceu (dep. fed. por São Paulo e presidente nacional do partido desde 1995), Aloízio Mercadante (Dir. Nac., dep. fed. por São Paulo 1991-94 e 1999-), Vicente Paulo da Silva (presidente nacional da Central Única dos Trabalhadores), Marco Aurélio Garcia (Dir. Nac.), Eduardo Suplicy (senador por São Paulo) e Benedita da Silva (Dir. Nac., vice-governadora do Rio de Janeiro eleita em 1998).

Democracia Radical: grupo situado mais à direita no partido e defensor decidido de alianças na direção do centro do espectro político-ideológico brasileiro. Alia-se sistematicamente à Articulação Unidade na Luta na disputa interna, embora apresente chapa própria em todos os Encontros analisados. Originário sobretudo das tendências Nova Esquerda e Vertente Socialista, que existiram na passagem da década de 80 para a de 90 . Principais lideranças: José Genoíno (dep. fed. por São Paulo, Dir. Nac.), Marina Silva (Dir. Nac. 1993-97, senadora eleita pelo Acre em 1994), Eduardo Jorge (dep. fed. por São Paulo, Dir. Nac. até 1995) e Tarso Genro exceto em 1999 (Dir. Nac., prefeito de Porto Alegre eleito em 1992).

Com o cenário já delineado, podemos passar à análise do conflito intrapartidário nos Encontros Nacionais nos quais a direção foi renovada. Procederei apresentando quatro tabelas referentes aos Encontros de 1993, 1995, 1997 e 1999, que informam o percentual de delegados das chapas, seus nomes e os das teses que apoiaram. As chapas estão dispostas no espectro político-ideológico da esquerda para a direita (ver Tabela 3).

Como se pode ver, a esquerda partidária, agrupada em duas chapas, conseguiu 55,59\% dos delegados e, por conseguinte, a maioria na direção nacional. A chapa Sem Medo de Ser Socialista pela Base com Independência, integrada por lideranças como os deputados federais Vladimir Palmeira (RJ), Jaques Wagner (BA) e Tilden Santiago (MG), não pode ser inscrita em nenhuma das alas, pois ao mesmo tempo em que criticava a direção de 1990-93, não se dispunha a se unir às tendências da esquerda partidária, constituindo portanto um pequeno centro diante dos dois campos. 
Alan Daniel Freire de Lacerda

Tabela 3

Configuração Interna do $8^{\circ}$ ENPT (1993)

\begin{tabular}{l|c|c|c|c|c}
\multicolumn{2}{c}{ Ala Esquerda } & Centro & \multicolumn{2}{c}{ Ala Direita } \\
\hline Chapas & Na Luta PT & $\begin{array}{c}\text { Uma Opção } \\
\text { de } \\
\text { Esquerda }\end{array}$ & $\begin{array}{c}\text { Sem Medo } \\
\text { de Ser } \\
\text { Socialista... }\end{array}$ & $\begin{array}{c}\text { Articulação } \\
\text { Unidade na } \\
\text { Luta }\end{array}$ & $\begin{array}{c}\text { Democracia } \\
\text { Radical }\end{array}$ \\
\hline $\begin{array}{l}\text { Número de } \\
\text { delegados }\end{array}$ & 99 & 189 & 18 & 152 & 60 \\
Teses & $\begin{array}{c}\text { Mesmo } \\
\text { nome } \\
107 \text { votos }\end{array}$ & $\begin{array}{c}\text { Mesmo } \\
\text { nome } \\
\text { Tese-guia } \\
189 \text { votos }\end{array}$ & $\begin{array}{c}\text { Não } \\
\text { aprentou } \\
\text { tese }\end{array}$ & $\begin{array}{c}\text { Mesmo } \\
\text { nome } \\
143 \text { votos }\end{array}$ & $\begin{array}{c}\text { "Puara } \\
\text { Brasil" } \\
50 \text { votos }\end{array}$ \\
\hline
\end{tabular}

Fonte: REC.

A maioria da esquerda petista apresentou sérias divergências em seu seio e não conseguiu estabilizar um novo núcleo dirigente para o partido durante seu mandato. Isto foi agravado pelo modo como foi enfrentada a difícil campanha presidencial de 1994 a partir da ascensão do candidato adversário Fernando Henrique Cardoso. A inexistência da pretendida maioria esquerdista forneceu incentivos para que a ala direita do partido retomasse o controle da direção nacional, o que de fato aconteceu no $10^{\circ}$ Encontro Nacional, ocorrido em agosto de 1995. O resultado pode ser visualizado na Tabela 4.

Tabela 4

Configuração Interna do $10^{\circ}$ ENPT (1995)

\begin{tabular}{|c|c|c|c|c|}
\hline \multicolumn{2}{|r|}{ Ala Esquerda } & Centro & \multicolumn{2}{|c|}{ Ala Direita } \\
\hline Chapas & $\begin{array}{l}\text { Socialismo e } \\
\text { Democracia }\end{array}$ & $\begin{array}{l}\text { Velhos Sonhos, } \\
\text { Novos Desafios }\end{array}$ & $\begin{array}{c}\text { Articulação } \\
\text { Unidade na } \\
\text { Luta }\end{array}$ & $\begin{array}{c}\text { Democracia } \\
\text { Radical }\end{array}$ \\
\hline $\begin{array}{l}\text { Número de } \\
\text { delegados }\end{array}$ & $\begin{array}{c}189 \\
(46,21 \%) \\
\end{array}$ & $\begin{array}{c}24 \\
(5,87 \%) \\
\end{array}$ & $\begin{array}{c}165 \\
(40,34 \%) \\
\end{array}$ & $\begin{array}{c}31 \\
(7,58 \%) \\
\end{array}$ \\
\hline Teses & $\begin{array}{c}\text { "O PT na Luta } \\
\text { contra o } \\
\text { Neoliberalismo" } \\
\text { e "Uma Opção } \\
\text { de Esquerda" }\end{array}$ & $\begin{array}{c}\text { "Novas } \\
\text { Realidades, } \\
\text { Velhos Desafios" }\end{array}$ & $\begin{array}{c}\text { Mesmo nome } \\
\text { Tese-guia }\end{array}$ & $\begin{array}{l}\text { "Afirmando } \\
\text { Alternativas" }\end{array}$ \\
\hline
\end{tabular}

Fonte: REC.

Obs.: Na fonte não há dados sobre a votação das teses. 
Diante da iminência de perda do controle da direção nacional, os grupos Na Luta PT e Uma Opção de Esquerda reuniram-se em uma só chapa, a mais votada no Encontro. Este teve um caráter especial, pois foi a primeira vez em que houve uma disputa pela presidência nacional do partido, com a recusa de Lula em continuar no cargo, o que contribuiu para polarizar as posições das facções. A ala direita conseguiu fechar um acordo com a chapa de centro Velhos Sonhos, Novos Desafios, composta pelas lideranças já citadas da chapa de centro do Encontro anterior acrescida de lideranças egressas da Articulação de Esquerda, como Rui Falcão e Cândido Vacarezza. Isso permitiu que José Dirceu ascendesse à presidência, ao obter 215 votos (54,02\%) contra 183 $(45,98 \%)$ de Hamilton Pereira, candidato da ala esquerda (REC 614). Assim, apesar de não obter maioria absoluta na direção nacional, a ala direita pôde reconstituir um novo núcleo dirigente, majoritário, com a anuência do pequeno setor centrista.

Do ponto de vista do conflito interno, a principal dificuldade no período 1995-97 foi a disputa em torno do cargo de secretário-geral do partido, desejado pela chapa Socialismo e Democracia a partir do grande número de delegados que obteve no Encontro. Como a maioria récem-formada fechou questão em torno do nome de Cândido Vacarezza, não houve acordo para a constituição da Executiva, e por um ano a esquerda ficou excluída da mesma, em um episódio que demonstra a intensidade dos conflitos internos petistas. Nem por isso, a nova direção ficou imobilizada, reestruturando as finanças do partido, definindo uma linha oposicionista em relação ao governo e dirigindo firmemente o processo das eleições municipais de 1996. A ala direita colheu os frutos de sua direção no 11ํㅡㄹ Encontro Nacional, no qual atinge maioria absoluta dos delegados, conforme demonstra a Tabela 5.

As três chapas componentes da ala direita perfazem, somadas, $51,10 \%$ dos delegados. A chapa Nova Democracia, cuja tese pouco difere da tese Articulação Unidade na Luta, era composta pelas lideranças que saíram da Articulação de Esquerda em 1995, as quais foram plenamente integradas à Unidade na Luta no $2^{\circ}$ Congresso em 1999. Novamente uma chapa única da esquerda foi a mais votada. Importante também nesse Encontro foi a ampliação do campo centrista que, além dos líderes da chapa centrista de 1993, incluiu setores que até então influenciavam marginalmente a política do partido. Contudo, sua chapa, a Socialismo e Liberdade, ficou inclinada à esquerda ${ }^{21}$ na dinâmi- 
Alan Daniel Freire de Lacerda

Tabela 5

Configuração Interna do 11ํㅡㄹ ENP (1997)

\begin{tabular}{|c|c|c|c|c|c|}
\hline \multicolumn{2}{|r|}{ Ala Esquerda } & \multicolumn{3}{|c|}{ Ala Direita } & \multirow[b]{2}{*}{$\begin{array}{c}\text { Democracia } \\
\text { Radical }\end{array}$} \\
\hline Chapas & Luta Socialista & \begin{tabular}{|} 
Socialismo \\
$\mathrm{e}$ \\
Liberdade
\end{tabular} & $\begin{array}{c}\text { Nova } \\
\text { Democracia }\end{array}$ & $\begin{array}{c}\text { Articulação } \\
\text { Unidade na } \\
\text { Luta }\end{array}$ & \\
\hline $\begin{array}{l}\text { Número de } \\
\text { delegados }\end{array}$ & $\begin{array}{c}208 \\
(37,82 \%)\end{array}$ & $\begin{array}{c}61 \\
(11,09 \%)\end{array}$ & $\begin{array}{c}25 \\
(4,55 \%)\end{array}$ & $\begin{array}{c}191 \\
(34,73 \%)\end{array}$ & $\begin{array}{c}65 \\
(11,82 \%)\end{array}$ \\
\hline Teses & \begin{tabular}{|c|} 
“Mudar o PT \\
para Mudar o \\
Brasil" \\
176 votos \\
"Posição do PT \\
na Campanha \\
Eleitoral de \\
1998" \\
31 votos \\
“Com os \\
Trabalhadores \\
pelos Direitos e \\
Reivindicações" \\
17 votos \\
"É Possível \\
Resistir. Basta \\
Querer" \\
33 votos
\end{tabular} & \begin{tabular}{|c|} 
"É Possível \\
Resistir. \\
Basta \\
Querer" \\
33 votos
\end{tabular} & $\begin{array}{c}\text { "Construindo } \\
\text { uma Nova } \\
\text { Democracia" } \\
16 \text { votos }\end{array}$ & $\begin{array}{c}\text { Mesmo } \\
\text { nome } \\
\text { Tese-guia } \\
222 \text { votos }\end{array}$ & $\begin{array}{l}\text { "Aprofundar } \\
\text { a Democracia: } \\
\text { Tarefa } \\
\text { Histórica do } \\
\text { PT" } \\
42 \text { votos }\end{array}$ \\
\hline
\end{tabular}

Fonte: REC.

ca do Encontro, pois muitos de seus apoiadores assinaram a tese "É possível resistir. Basta querer", encabeçada por Arlindo Chinaglia, líder da Articulação de Esquerda, bastante crítica à direção 1995-97. Além disso, os centristas apoiaram o deputado federal Milton Temer (RJ) na disputa pela presidência do partido, que assim obteve 256 votos $(47,41 \%)$ contra José Dirceu, que foi reeleito com 284 votos $(52,59 \%)($ REC 650).

O período 1997-99 vivencia um novo conflito interno grave. No Encontro estadual de 1998, o PT do Rio de Janeiro toma a decisão de lançar a candidatura de Vladimir Palmeira para governador, contrariando orientação nacional de apoio a Anthony Garotinho, candidato do PDT. A 
decisão do PT fluminense é derrubada, primeiro no Diretório Nacional e, após recurso, no Encontro Nacional Extraordinário de 1998. A prevalência da posição nacional só se deu após agudo conflito da ala direita com os setores agrupados em torno de Milton Temer, que radicalizou suas posições de crítica interna naquele momento. O episódio fortaleceu as intenções de líderes que queriam realizar uma "descompressão" na bipolaridade existente no partido, através da criação de um setor centrista mais forte e independente. Isso se deu no $2^{\circ}$ Congresso, ocorrido em novembro de 1999, como se observa na Tabela 6.

Tabela 6

Configuração Interna do 2 ํ Congresso (1999)

\begin{tabular}{l|c|c|c|c|c|c|c}
\multicolumn{9}{c}{ Ala Esquerda } & \multicolumn{2}{c}{ Centro } & \multicolumn{2}{c}{ Ala Direita } \\
\hline Chapas & $\begin{array}{c}\text { Fiel ao PT } \\
\text { das Ori- } \\
\text { gens }\end{array}$ & $\begin{array}{c}\text { Socialis- } \\
\text { mo ou } \\
\text { Barbárie }\end{array}$ & $\begin{array}{c}\text { Nosso } \\
\text { Tempo }\end{array}$ & $\begin{array}{c}\text { Movimen- } \\
\text { to PT }\end{array}$ & $\begin{array}{c}\text { PT de Lu- } \\
\text { tas e de } \\
\text { Massas }\end{array}$ & $\begin{array}{c}\text { Revolução } \\
\text { Democrá- } \\
\text { tica }\end{array}$ & $\begin{array}{c}\text { Democra- } \\
\text { cia Radical }\end{array}$ \\
\hline $\begin{array}{l}\text { Número } \\
\text { de delega- } \\
\text { dos }\end{array}$ & 19 & 190 & 90 & 116 & 26 & 398 & 73 \\
$(2,08 \%)$ & $(20,83 \%)$ & $(9,86 \%)$ & $(12,71 \%)$ & $(2,85 \%)$ & $(43,64 \%)$ & $(8 \%)$ \\
\hline Teses & $\begin{array}{c}\text { Não apre- } \\
\text { sentou tese }\end{array}$ & $\begin{array}{c}\text { Mesmo } \\
\text { nome }\end{array}$ & $\begin{array}{c}\text { Mesmo } \\
\text { nome }\end{array}$ & $\begin{array}{c}\text { "Retomar a } \\
\text { Iniciativa" }\end{array}$ & $\begin{array}{c}\text { "Programa } \\
\text { da Revolu- } \\
\text { ção Demo- } \\
\text { crática" } \\
\text { Tese-guia } \\
\text { ção Revolu- } \\
\text { crática" } \\
\text { Tese-guia }\end{array}$ & $\begin{array}{c}\text { Democra- } \\
\text { cia Repu- } \\
\text { blicana" }\end{array}$ \\
\hline
\end{tabular}

Fontes: Caderno de Teses do 2ํㅡㄹ Congresso; Jornal Em Tempo, no 311/312, nov./dez. de 1999. Os dados das votações das teses não estão disponíveis.

A ala direita reforçou sua maioria, obtendo $54,49 \%$ dos delegados, distribuídos em três chapas novamente. A tese-guia é a da tendência Articulação Unidade na Luta, cuja chapa foi a mais votada para o Diretório. A esquerda petista, distribuída também em três chapas, e portanto abandonando a postura de unidade em chapa que mantinha desde 1995, obteve 32,77\% dos delegados. O setor de centro, agrupado na chapa Movimento PT, tinha como líderes Arlindo Chinaglia, que se candidatou à presidência do partido, o deputado federal Carlos Santana (RJ), os já citados Tilden Santiago e Jaques Wagner, e Tarso Genro, ex-prefeito de Porto Alegre egresso da Democracia Radical. José Dirceu alcançou sua melhor votação, sendo reeleito presidente com 496 votos (54,8\%), Milton Temer obteve 296 votos (32,7\%) e Arlindo Chinaglia 113 (12,48\%). O Congresso parece ter estabilizado a atual maioria como núcleo dirigente, além de contornar uma bipolaridade que poderia comprometer a unidade da organização partidária. 


\section{DISCUSSÃO E CONCLUSÃO}

Nesta seção, discutirei os efeitos de cada uma das três variáveis do modelo no caso estudado, sempre em comparação com as premissas do modelo. A recuperação das premissas do modelo nos informa que partidos de tipo inclusivo-competitivo possuem arranjos internos que induzem à manutenção da unidade partidária através de dois mecanismos. Primeiramente, há que se notar a existência de oportunidades reguladas abertas às facções de disputar os votos dos filiados em conjunto com amplos direitos de participação dos filiados, que detêm, formalmente, a fonte da autoridade na organização. Em segundo lugar, a conformação das instâncias internas como fóruns nos quais o filiado/militante discute e delibera acerca dos destinos da organização, sentindo-se, portanto, co-partícipe das decisões. Por um lado, grupos que saem do partido devem estar dispostos a incorrer em custos como a perda de cargos dirigentes e o controle de recursos organizacionais; por outro, os membros desses grupos deixam de participar de uma arena que, mesmo dirigida efetivamente por Executivas, lhes oferece co-participação através de reuniões periódicas de deliberação e discussão.

O PT sempre se afirmou como partido democraticamente dirigido a partir dessas duas características e, embora haja muito de ideológico nessa auto-afirmação, a estrutura interna apresenta-as em larga escala. Senão, como explicar os encontros participativos e competitivos, às vezes imprevisíveis, que são vistos no partido? E as movimentações, fusões e realinhamentos de chapas analisados na seção anterior? Por trás de toda a confusão dos grupos e de seus conflitos, a unidade partidária vem se mantendo ao longo de mais de vinte anos, e pudemos comprovar que o arranjo petista teve papel fundamental para esse resultado.

De acordo com as premissas do modelo, desacordos ideológicos internos ao partido podem ser divididos em duas categorias ou dimensões: 1) definição de objetivos ideológicos originados na fundação do partido e 2) definição de programas de políticas públicas que o partido propõe para o eleitorado. Minha premissa dá igual peso a ambos, mas devemos observar que existem partidos nos quais a primeira dimensão não interessa (por exemplo, partidos sem compromissos ideológicos definidos) e os conflitos se concentram na segunda. 
No PT, encontramos discordâncias importantes nas duas categorias, com relação tanto ao papel das instituições representativas na persecução do objetivo socialista quanto à política de alianças, indicador que utilizei para o segundo tipo de divergência. A verdade é que as duas dimensões se fundem no caso petista, sendo difícil separar uma da outra no terreno empírico ${ }^{22}$. O conflito interno pode ser visto como uma disputa de posições no continuum ideológico esquerda-direita. A esquerda defende que a luta social tem precedência sobre a ampliação do poder dentro das instituições representativas - tal ampliação só faz sentido como efeito da luta social-, sustenta que a luta pelo socialismo requer a predominância de mecanismos de democracia direta, e defende uma política de alianças restrita aos partidos de esquerda. A direita sustenta que luta social e institucional caminham juntas, dá importância similar aos mecanismos de democracia representativa em relação aos de democracia direta, e propõe alianças com setores de centro.

A divergência ideológica entre grupos internos, diferentemente da primeira variável, pode de fato levar à cisão partidária, no caso de haver um acirramento do conflito atual. Mas esta variável deve ser vista em conjunto com as outras.

Os custos externos se mostraram elevados, sobretudo em função da força eleitoral crescente do partido, mas também de seus consideráveis níveis de identificação partidária no eleitorado e da evidência indireta representada pelo raquitismo eleitoral do produto da única cisão significativa ocorrida no PT em vinte anos: o PST-U. A tendência que formou a maioria desse novo partido, a Convergência Socialista, possuía deputados federais e estaduais (em geral suplentes) antes do pleito de 1994, e perdeu tais posições. Pequenos grupos de posições próximas às do PST-U, como as tendências O Trabalho e CST, permanecem no PT até hoje, mesmo sofrendo um certo grau de hostilidade de amplos setores partidários, sem dúvida atentos à "evidência indireta" que mencionamos.

Minha conclusão, em consonância com as expectativas do modelo, é que as induções presentes no terreno das regras intrapartidárias ${ }^{23}$ e os custos eleitorais da cisão se mostram suficientemente fortes para desestimularem qualquer tentativa de saída de uma ou mais facções, no atual cenário petista e em seu futuro previsível. Tais induções, segundo minha avaliação, superam os efeitos da discordância ideológica 


\section{Alan Daniel Freire de Lacerda}

que aferi. Em minha apreciação, o PT encontra-se em uma situação de equilíbrio na qual não interessa a nenhum dos atores sair do partido.

Como observação final, devo enfatizar um ponto, que talvez já tenha ficado claro dadas as opções teórico-metodológicas que fiz ao longo do trabalho. Afinal, como classificar o PT? Seria o partido uma frente? Uma coalizão? Tais expressões são usadas corriqueiramente quando se discute o partido, até mesmo pelos próprios petistas. Discordo de ambas, por considerar que refletem preconceitos em relação a partidos com estruturas inclusivo-competitivas (no caso da adoção do termo frente) e um uso demasiado elástico do conceito de coalizão. A meu ver, o PT é um partido político que desenvolveu historicamente estruturas internas permeáveis à atuação de facções internas e uma particular distribuição de preferências ideológicas entre seus filiados. A interação de ambas define o caráter e a intensidade da luta interna petista. Outros partidos políticos brasileiros se desenvolveram de outras maneiras, considerando-se as circunstâncias com que se defrontaram e as escolhas que fizeram.

(Recebido para publicação em fevereiro de 2001) (Versão definitiva em janeiro de 2002)

\section{NOTAS}

1. Enfatizo os custos eleitorais da cisão, mas também devem ser considerados os custos organizacionais.

2. Dahl classifica diversos regimes políticos de acordo com a mensuração da realização (que pode ser não concomitante) das duas dimensões, e denomina de poliarquias os regimes com substancial (mas não completa) inclusão eleitoral e ampla (também não completa) institucionalização da competição.

3. Os adjetivos "baixa" e "alta" são usados aqui com objetivos propositalmente simplificadores, no intuito de facilitar a apresentação do modelo e o agrupamento dos partidos em tipos idealmente definidos.

4. Partido dos Trabalhadores (1998), Resoluções de Encontros e Congressos 1979-1998, pp. 47-48. Daqui por diante as referências a este importante trabalho serão inscritas no corpo do texto como REC, seguido do número da(s) página(s).

5. Qualificações a essas autodefinições petistas podem ser encontradas em Rodrigues (1990). O autor aponta a participação na formação do partido de importantes insti- 


\section{O PT e a Unidade Partidária como Problema}

tuições, como a Igreja Católica e os sindicatos, o que contribui para limitar o alcance da visão "basista" que o partido propaga a seu próprio respeito.

6. OPT, insatisfeito com as exigências da legislação partidária que restabeleceu o pluripartidarismo em 1979, criou uma sistemática de funcionamento extra-oficial, na qual os Encontros são o principal fórum deliberativo. As Convenções, requeridas pela legislação, apenas homologam e referendam as resoluções aprovadas e direções eleitas nos Encontros. Tal sistemática persiste até hoje, apesar das mudanças consideráveis na legislação.

7. Dezoito cargos na Executiva são preenchidos por critérios proporcionais. O presidente nacional do partido é eleito diretamente pelos delegados. Os líderes na Câmara e no Senado são eleitos por suas respectivas bancadas no início do ano legislativo.

8. Várias provisões importantes para o funcionamento do PT não são discutidas aqui, por estarem fora do escopo do trabalho. Como exemplos, temos: a reserva de $30 \%$ de cargos dirigentes para mulheres, aplicada a partir de 1991; possibilidade de ocupação de postos de direção nacional por delegados setoriais estaduais representando minorias como negros, índios, deficientes físicos etc.; e instâncias de base como plenárias municipais e núcleos (cf. Estatuto e Regimento Interno do PT e regulamentos de Encontros).

9. Pré-teses e teses são documentos apresentados por grupos de filiados para discussão no período que antecede o Encontro Nacional. A tese-guia é aquela que obtém uma maioria simples no Encontro, servindo para orientar os debates subseqüentes, podendo ser emendada, mas não alterada em suas linhas fundamentais. Em geral, as lideranças de cada facção elaboram sua própria tese, submetendo-a às contribuições do conjunto de filiados ligados à facção e à apreciação do restante do partido.

10. Para a história e descrição do período inicial do PT, as referências são Meneguello (1989) e Keck (1991).

11. O discurso é considerado um documento oficial e fundamental do partido até hoje.

12. Porém, a resolução adverte que grande parte das organizações presentes na nova sociedade não podem e não devem ser abolidas por decreto.

13. O Congresso tem o mesmo formato de um Encontro, com as diferenças de que possui um grande número de delegados (o 1ํㅡㄹ contava com 1196 e o 2ํ- 1999 - com 927 delegados) e uma pretensão de elaboração programática e definição de rumos partidários mais ambiciosa.

14. A corrente Democracia Radical, na sua tese "Por uma democracia republicana" apresentada ao $2^{\circ}$ Congresso, decidiu não se referir ao socialismo, por considerar o termo vinculado aos regimes socialistas ditatoriais. Sem dúvida, isso aprofunda a divergência com a esquerda petista, que exige sempre referências ao objetivo estratégico partidário. Contudo, deve-se notar que, no restante das questões, as posições da corrente se coadunam com as demais presentes na direita petista.

15. As posições foram encontradas no Caderno de Pré-Teses de 1993 e nos Cadernos de Teses de 1997 e 1999. No Caderno de Teses de 1995 não encontramos propostas das facções a respeito desse tópico. 


\section{Alan Daniel Freire de Lacerda}

16. Outro caso de derrota de ex-petista é o de Jacó Bittar em Campinas. Também há casos de vitoriosos como Maurício Soares em São Bernardo do Campo e Gilson Menezes em Diadema.

17. Folha de S. Paulo, de 16/9/1994, Caderno Especial, p. 2. É importante salientar que simpatia não significa necessariamente que o simpatizante vote no partido.

18. Na Central Única dos Trabalhadores - CUT, fundada na mesma época, também passou a existir uma corrente majoritária, a Articulação Sindical, que praticamente tinha a mesma composição de sua correspondente petista. Isso mostra a forte influência que o setor sindical detinha na Articulação e no PT como um todo.

19. O grupo era originário das tendências Nova Esquerda e Vertente Socialista, que completavam um processo de revisão dos princípios marxistas que as norteavam. O próprio Genoíno era um importante líder da ala esquerda do partido nos Encontros anteriores, encabeçando a chapa Luta Socialista, a mais importante da ala no $5^{\circ}$ Encontro Nacional.

20. Quando não há indicação de data, a pessoa exerceu a(s) função(ões) indicada(s) entre parênteses durante todo o período que vai de 1990 a 1999.

21. Não obstante tal fato, classifiquei o grupo como centrista dado seu comportamento em 1999.

22. Devemos anotar, no entanto, a perene autonomia de decisões referidas às alianças eleitorais e governativas. Tanto políticos de esquerda quanto de direita dentro do PT, quando decidindo táticas eleitorais ou principalmente a construção de coalizões governativas, podem se distanciar do quadro ideológico-fundacional partidário. Destaco somente que esta é uma restrição ao movimento dos políticos em tal direção.

23. É preciso fazer referência a iniciativas recentes que alteraram o arranjo petista. Trata-se da mudança estatutária aprovada no $2^{\circ}$ Congresso em 1999 e aplicada na renovação de presidentes e diretórios em setembro de 2001. A medida instituiu eleições diretas - ou seja, não nos Encontros - das direções e presidentes em todos os níveis. A proposta foi aprovada pela atual maioria partidária, com forte polêmica e sob a oposição da esquerda partidária, que temia perder espaço nas direções, dada a força eleitoral dos políticos da ala direita. A julgar pelos resultados das eleições diretas, os temores eram infundados. $\mathrm{O}$ arranjo permanece basicamente o mesmo, com maior aprofundamento da inclusão de filiados no processo decisório, já que os Encontros permanecem como instâncias deliberativas máximas dentro da estrutura partidária. 


\section{O PT e a Unidade Partidária como Problema}

\section{REFERÊNCIAS BIBLIOGRÁFICAS}

AZEVEDO, Clóvis B. de. (1995), A Estrela Partida ao Meio: Ambigüidades do Pensamento Petista. São Paulo, Entrelinhas.

DAHL, Robert. (1997), Poliarquia: Participação e Oposição. São Paulo, EdusP.

KECK, Margaret. (1991), PT: A Lógica da Diferença. São Paulo, Ática.

LAVER, Michael e SCHOFIELD, Norman. (1990), Multiparty Government: The Politics of Coalition in Europe. Oxford, Oxford University Press.

LEAL, Paulo R. F. (1997), A Encruzilhada do PT: A Lógica da Representação versus Mercado Eleitoral. Dissertação de Mestrado, IUPERJ, Rio de Janeiro.

LESSA, Renato. (1999), A Invenção Republicana (2ª ed.). Rio de Janeiro, Topbooks.

MELO, Carlos Ranulfo F. de. (1994), O PT e a Democracia. Dissertação de Mestrado, UFMG, Belo Horizonte.

MENEGUELLO, Rachel. (1989), PT: A Formação de um Partido, 1979-1982. Rio de Janeiro, Paz e Terra.

MICHELS, Robert. (1962), Political Parties: A Sociological Study of the Oligarchical Tendencies of Modern Democracy. New York, Free Press.

MÜLLER, Wolfgang C. e STROM, Kaare (eds.). (1999), Policy, Office or Votes: How Political Parties in Western Europe Make Hard Decisions. Cambridge, Cambridge University Press.

NICOLAU, Jairo Marconi (org.). (1998), Dados Eleitorais do Brasil (1982-1996). Rio de Janeiro, Revan/IUPERJ-UCAM.

NOVAES, Carlos A. Marques. (1993), "PT: Dilemas da Burocratização". Novos Estudos CEBRAP, n우 35, pp. 217-237.

PARTIDO DOS TRABALHADORES. (1998), Resoluções de Encontros e Congressos 1979-1998. São Paulo, Ed. Fundação Perseu Abramo.

RODRIGUES, Leôncio Martins. (1990), "A Composição Social da Liderança do PT", in Partidos e Sindicatos: Escritos de Sociologia e Política. São Paulo, Ática.

STROM, Kaare. (1990), "A Behavioral Theory of Competitive Political Parties". American Journal of Political Science, vol. 34, nํ2, pp. 565-598. 


\section{Alan Daniel Freire de Lacerda}

\section{ABSTRACT}

The Brazilian Workers' Party (PT) and the Party Unity Issue

This article analyzes the issue of party unity, investigating the factors that favor or discourage party breaks. Three independent variables are proposed, forming a model that seeks to evaluate the possibilities for splitting or maintaining party organization. The variables are the intra-partisan institutional arrangement, internal ideological dissent, and the electoral costs of a split. The model is applied to the case of the Workers' Party (PT), seeking to evaluate which factors are the strongest in this party, those leading to a split or those favoring maintenance of unity in the party's organization. The study draws on various data sources, including party documents and bylaws, theses proposed by party factions, and election results, covering four national events in the 1990s. The study contends that intra-partisan institutional arrangements and the electoral costs of a split have strongly discouraged any break in the PT as a political party, and that if all else remains constant, these factors will continue to produce the same effects in the foreseeable future.

Key words: political party; party organization; Workers' Party

\section{RÉSUMÉ \\ Le Parti des Travailleurs et la Question de l'Unité des Partis}

Dans cet article, on examine la question de l'unité des partis, en cherchant à déceler les facteurs qui provoquent ou empêchent leur scission. On propose trois variables indépendantes formant un modèle qui tente d'évaluer les chances de scission/maintien d'une organisation de parti. Ces variables sont les suivantes: l'aménagement institutionnel et la divergence idéologique internes au parti ainsi que les pertes électorales d'une scission. On applique ce modèle au cas du Parti des Travailleurs (PT), en cherchant à estimer ce qui y prévaut: les tendances qui mènent à la scission ou celles qui favorisent le maintien de l'unité du parti. La recherche se sert de plusieurs sortes de données, telles que documents et statuts du parti, thèses des factions internes et résultats d'élections, concernant surtout quatre rencontres nationales réalisées dans les années 90 . On conclut que les aménagements institutionnels internes au parti et les pertes électorales d'une scission éloignent nettement la perspective du fractionnement du PT en tant que parti politique et, toutes conditions gardées, auront le même effet dans un avenir prévisible.

Mots-clé: parti politique; organisation des partis; Parti des Travailleurs 